\title{
Evaluation of Health Promotive and Protective Behaviors in Terms of Different Qualities: A Study on Physical Education Teachers
}

\author{
Çağdaş Caz ${ }^{1, *} \&$ Mehmet Yıldırım ${ }^{1}$ \\ ${ }^{1}$ School of Physical Education and Sport, Yozgat Bozok University, Yozgat, Turkey \\ *Correspondence: School of Physical Education and Sport, Yozgat Bozok University, Yozgat, Turkey. E-mail: \\ cazcagdas@gmail.com
}

Received: November 2, 2018

Accepted: January 2, 2019 Online Published: January 21, 2019

doi:10.5430/wje.v9n1p64

URL: https://doi.org/10.5430/wje.v9n1p64

\begin{abstract}
Health is one of the most valuable things that we can have. The first thing that comes to mind when we think of health is our physical structure. However, mental health is also of crucial importance. In this context, the aim of this study is to examine physical education teachers' health promoting and protective behaviors in terms of different qualities. Study sample consisted of 42 female and 98 male physical education teachers. Data were collected using the Health Promoting and Protective Behaviors Scale (HPPBS) developed by Bostan, Örsal \& Montenegro (2016). Data were descriptively analyzed. T-test and one-way analysis of variance (ANOVA) were used for independent groups. Tukey's multiple comparison test was used for posthoc pairwise comparisons to determine the source of difference. Health promoting and protective behaviors did not differ significantly by gender. However, there was a statistically significant difference in health promoting and protective behaviors between participants who have regular check-ups and pay attention to their diet and sleep and those who do not.
\end{abstract}

Keywords: physical education teachers, health promoting and protective behaviors, demographic variables

\section{Introduction}

Recent scientific research aims to preserve, maintain and improve community health. A healthy society consists of healthy individuals. Addressing biological factors affecting and/or causing disease and illness, medical research focused on treatments until some time ago. However, today, it has adopted a preventative approach to encourage changes in people's lifestyles and to modify their risky behaviors before they become ill. People should, therefore, be provided with information and support that they need to develop positive behaviors to maintain and improve their health and well-being and to make the right health decisions (Kong, 1995).

The World Health Organization defines health as a state of complete physical, mental and social well-being and not merely the absence of disease and infirmity (WHO, 2011). Health is a broad concept that includes protection, self-care, individual responsibility, optimal well-being, quality of life and health behavior (Yardım et al., 2009). Health plays an important role in our life. It is a widely accepted philosophy that health care is a right, not a privilege (Babadağ, 2001). When people become ill, they naturally seek health care. However, the philosophical basis of contemporary public health is to make sure that people protect and improve their health before they face sickness (Öztek, Üner, \& Eren, 2012).

The implementation of health promotion initiatives leads to a drastic reduction in the prevalence of diseases, an extension of life span and an improvement of quality of life, resulting in a healthy society. The subsidiary outcomes of health promotion initiatives are the prevention of risk factors for health in the short term and the development of positive health behaviors, regulation of lifestyles and provision of healthy environmental changes in the medium term. The areas of intervention to improve health are education, management, and legal and structural regulations (Özvarış, 2011). Health promotion is to maximize health behavior change. Health is a fundamental right of every human being. The improvement and maintenance of health is not only the responsibility of health care professionals but also of the individual (Ayaz, Tezcan, \& Akınc1, 2005). Health promotion is a process of improving people's physical and mental health, and helping them make the right health decisions (Güngör \& Hatun, 2006). Health promotion is the mobilization of educational, social and environmental resources to enable people to develop and maintain behaviors 
that reduce the risk of illness and promote well-being. Health education lies at the heart of health promotion. Health education is defined as any kind of learning experience designed to promote change in people's thoughts, beliefs, attitudes, behaviors and lifestyles related to their own health (Evren, 2008). Healthy lifestyle is defined as a way of life in which people control their behaviors affecting their health and organize their daily activities by choosing behaviors appropriate to their health status (Özkan \& Yılmaz, 2008). Health behavior is a constellation of practices that people engage in to stay healthy and to protect themselves from disease (Zaybak \& Fadıllıoğlu, 2004). People can develop healthy lifestyle behaviors by changing their knowledge, thoughts and values. Health education should, therefore, be provided to general public (Altiparmak \& Kutlu, 2009). Health education primarily helps to determine behaviors that endanger the health of individuals and the community, and to identify and change the causes of those behaviors. Due to their professional responsibilities, social roles, lifestyles and potential to become role models, teachers have the ability to influence their students' attitudes and views. They, therefore, play a key role in the education of children in terms of health protection and development (Özkan \& Yılmaz, 2008) and are expected to have sufficient knowledge on health promoting behaviors because an educator who does not care about his/her health cannot improve his/her students' health promoting behaviors (Karadeniz et al., 2008). However, the number of studies on teachers' health behaviors is limited. We, therefore, believe that this study will contribute to the literature by determining physical education teachers' health promoting and protective behaviors and identifying factors that differentiate their health behaviors. We expect that the results will guide health professionals and health management authorities for further development of health interventions for communities. In this context, the aim of this study is to examine physical education teachers' health promoting and protective behaviors in terms of gender, age, regular health check, paying attention to diet and sleep.

\section{Method}

\subsection{Study Sample}

The study sample consisted of 42 female and 98 male physical education teachers.

\subsection{Data Collection}

Data were collected using the Health Promoting and Protective Behaviors Scale (HPPBS) developed by Bostan, Örsal \& Montenegro (2016).

The HPPBS is a five-point Likert-type scale consisting of 3 subscales (physical, psychosocial and protection) and 24 items. The scale items are scored from 1 to 5 ("Never $=1$," "Very Rarely $=2$," "Occasionally = 3," "Most of the Time $=4$," "Always $=5$ "). The Cronbach's alpha of the scale was 0.83 , and the Cronbach's alpha of the sub-scales ranged from 0.61 to 0.76 . The higher the score, the more health promoting (regular exercise, meeting physiological requirements such as eating and drinking, making time for oneself and family etc.) and protective behaviors (Bostan et al., 2016).

\subsection{Data Collection}

The HPPBS and the "Personal Information Form" were transferred to the online environment. Participants were emailed the link to the scale and form. Participants filled them out and returned them. Data were first sorted out and then analyzed.

\subsection{Data Analysis}

Normality test was used to determine whether the data were normally distributed. Descriptive values were presented for the data showing normal distribution. T-test and one-way analysis of variance (ANOVA) was used for independent groups. The Tukey's test was used to determine which of the means differed.

\section{Results}

Table 1. Scale Score Distribution

\begin{tabular}{lccccccc}
\hline Scale and sub-scales & $\mathbf{N}$ & Min. & Max. & Mean & SD & Skewness & Kurtosis \\
\hline Physical & 140 & 23.00 & 49.00 & 35.93 & 5.15 & .239 & -.314 \\
Psychosocial & 140 & 14.00 & 30.00 & 21.10 & 3.51 & .185 & -.380 \\
$\begin{array}{l}\text { Protection } \\
\text { Health Promoting and }\end{array}$ & 140 & 16.00 & 38.00 & 27.79 & 4.91 & -.004 & -.601 \\
Protective Behaviors Total & 140 & 58.00 & 111.00 & 84.82 & 11.05 & -.072 & -.575 \\
\hline
\end{tabular}


The data showed normal distribution. Table 1 shows that participants' mean scores on the HPPBS are high.

Table 2. Comparison of Scale Scores by Gender

\begin{tabular}{lcccccc}
\hline Scale and sub-scales & Gender & N & Mean & SD & t & P \\
\hline \multirow{2}{*}{ Physical } & Woman & 42 & 34.71 & 4.94 & \multirow{2}{*}{.850} & .067 \\
\multirow{2}{*}{ Psychosocial } & Man & 98 & 36.45 & 5.18 & & \\
\multirow{2}{*}{ Protection } & Woman & 42 & 21.28 & 4.00 & .408 & .684 \\
\multirow{2}{*}{ HPPBS Total } & Man & 98 & 21.02 & 3.29 & & \\
& Woman & 42 & 27.45 & 4.25 & -.535 & .594 \\
& Man & 98 & 27.93 & 5.18 & & \\
& Woman & 42 & 83.45 & 11.14 & -.964 & .337 \\
\hline
\end{tabular}

Although male participants had higher mean scores than did female participants, the mean scale scores did not differ significantly by gender, indicating that male and female participants have similar attitudes towards health promoting and protective behaviors.

Table 3. Comparison of Scale Scores by Age

\begin{tabular}{lccccccc}
\hline $\begin{array}{l}\text { Scale and } \\
\text { sub-scales }\end{array}$ & Age & N & Mean & SD & F & p & Sig. \\
\hline \multirow{3}{*}{ Physical } & 21-25 years & 17 & 37.58 & 5.45 & & & \\
& 26-30 years & 34 & 35.00 & 5.80 & 1.443 & .240 & -- \\
Psychosocial & 31 years and over & 89 & 35.97 & 4.80 & & & \\
& 21-25 years & 17 & 23.17 & 4.06 & & & 21-25 years and \\
& 26-30 years & 34 & 21.23 & 3.24 & 3.871 & $\mathbf{. 0 2 3}$ & 31 years and over \\
Protection & 31 years and over & 89 & 20.65 & 3.39 & & & \\
& 21-25 years & 17 & 28.64 & 5.81 & & & --- \\
& 26-30 years & 34 & 27.82 & 4.61 & .310 & .734 & \\
HPPBS Total & 31 years and over & 89 & 27.61 & 4.88 & & & -- \\
& 21-25 years & 17 & 89.41 & 12.59 & & & \\
\hline
\end{tabular}

The psychosocial subscale mean scores differed significantly by age. The mean scores of participants aged between 21 and 25 years were statistically significantly higher than those of participants 31 years of age and over.

Table 4. Comparison of Scale Scores by Regular Check-Ups

\begin{tabular}{lcccccc}
\hline Scale and sub-scales & Regular check-up & N & Mean & SD & t & p \\
\hline \multirow{2}{*}{ Physical } & Yes & 36 & 37.75 & 5.48 & \multirow{2}{*}{2.493} & $\mathbf{. 0 1 4}$ \\
Psychosocial & No & 104 & 35.30 & 4.91 & & \\
\multirow{4}{*}{ Protection } & Yes & 36 & 23.02 & 4.14 & 3.455 & $\mathbf{. 0 0 1}$ \\
& No & 104 & 20.43 & 3.01 & & \\
HPPBS Total & Yes & 36 & 29.50 & 4.45 & \multirow{2}{*}{2.460} & $\mathbf{. 0 1 5}$ \\
& No & 104 & 27.20 & 4.95 & & \\
& Yes & 36 & 90.27 & 10.45 & 3.574 & $\mathbf{. 0 0 0}$ \\
\hline
\end{tabular}

There was a statistically significant difference in scale and subscale mean scores between participants who have regular check-ups and those who do not in favor of the former $(p<0.05)$. In this context, the mean scores of participants who answered "yes" was high. 
Table 5. Comparison of Scale Scores by Paying Attention to Diet and Sleep

\begin{tabular}{lcccccc}
\hline $\begin{array}{l}\text { Scale and } \\
\text { sub-scales }\end{array}$ & $\begin{array}{c}\text { Paying attention to diet and } \\
\text { sleep }\end{array}$ & N & Mean & SD & t & p \\
\hline \multirow{2}{*}{ Physical } & Yes & 85 & 37.87 & 4.80 & \multirow{2}{*}{6.219} & $\mathbf{. 0 0 0}$ \\
& No & 55 & 32.94 & 4.19 & & \\
Psychosocial & Yes & 85 & 22.00 & 3.26 & 3.961 & $\mathbf{. 0 0 0}$ \\
& No & 55 & 19.70 & 3.45 & & \\
Protection & Yes & 85 & 29.38 & 4.69 & 5.200 & $\mathbf{. 0 0 0}$ \\
& No & 55 & 25.32 & 4.21 & & \\
HPPBS Total & Yes & 85 & 89.25 & 10.00 & 6.782 & $\mathbf{. 0 0 0}$ \\
& No & 55 & 77.98 & 8.95 & & \\
\hline
\end{tabular}

There was a statistically significant difference in scale and subscale mean scores between participants who pay attention to their diet and sleep and those who do not in favor of the former $(\mathrm{p}<0.05)$.

\section{Discussion}

The results show that participants' mean scores are high, indicating that their views of health promoting and protective behaviors are positive. Tokuç \& Berberoğlu (2007) found that teachers' health behaviors related to health promotion were generally good. Tambağ (2011) reported that students' scores on healthy lifestyle behaviors were moderate. In Yılmazel, Çetinkaya, \& Naçar (2013), nursing students' health promotion behavior scale scores were moderate. Sümen \& Öncel (2017) reported that high school students' scores on healthy lifestyle behaviors were generally moderate.

Participants' mean scale scores did not differ significantly by gender, indicating that male and female participants have similar attitudes towards health promoting and protective behaviors. Cihangiroğlu \& Deveci (2011) conducted a survey with health school students and found no relationship between gender and healthy lifestyle behaviors. Koçoğlu (2006) stated that gender has no effect on healthy lifestyle behaviors. However, Tambağ (2011) found that female students' scale scores were statistically significantly higher than those of male students. Vural \& Bakir (2015) reported that female students' health responsibility, nutrition and stress management sub-scale median scores were statistically significantly higher than those of male students. Turgul, Doğan, Mandıracıoğlu \& Lüleci (2002) found that women had more positive attitudes towards health promotion behaviors than did men. İlhan, Batmaz, \& Akhan (2010) found significant differences in healthy lifestyle behaviors between male and female university students. Yalçınkaya, Özer, \& Karamanoğlu (2007) reported significant differences in healthy lifestyle behaviors between male and female health professionals. Similarly, Kostak, Kurt, Süt, Akarsu, \& Ergül (2014) found that gender had an effect on healthy lifestyle behaviors.

Eating healthy and sleeping well are crucial for health. The results show that participants paying attention to their diet and sleep have more positive views of health promoting and protective behaviors, which indicates the association between health-related behaviors and paying attention to diet and sleep patterns. Yalçınkaya, Özer, \& Karamanoğlu (2007) reported a significant difference in health-related behaviors between health professionals who have a balanced diet and those who do not.

\section{Conclusion}

The data meet the normality assumptions. Participants' mean scores were high, indicating that their views of health promoting and protective behaviors are positive in general. This finding shows that physical education teachers pay attention to their health.

The mean scores did not significantly differ by gender, suggesting that male and female participants have similar attitudes towards health promoting and protective behaviors.

The psychosocial subscale mean scores of participants aged between 21 and 25 years were statistically significantly higher than those of participants 31 years of age, suggesting that younger physical education teachers are more conscious about and give more importance to health. 
There was a statistically significant difference in scale and subscale mean scores between participants who have regular check-ups and those who do not in favor of the former, indicating how health-related behaviors are put into practice. This finding shows that teachers who go to continuous health control live healthier than those who do not.

Eating healthy and sleeping well are crucial for health. Getting sufficient rest and making healthy food choices have many health benefits, both physically and mentally. Participants paying attention to their diet and sleep have more positive views of health promoting and protective behaviors, which is also an indication of how health-related behaviors are put into practice.

\section{References}

Altıparmak, S., \& Kutlu, A. K. (2009). 15-49 yaş grubu kadınlarda sağlı̆̆ı geliştirme davranışları ve etkileyen faktörler. TAF Preventive Medicine Bulletini, 8(5), 421-426.

Ayaz, S., Tezcan, S., \& Akıncı, F. (2005). Hemşirelik yüksekokulu öğrencilerinin sağlığı geliştirme davranışları. Cumhuriyet Üniversitesi Hemşirelik Dergisi, 9(2), 26-34.

Babadağ, K. (2001). Yardım etme bilim ve sanatında hasta hakları. İstanbul Üniversitesi F.N Hemşirelik Bülteni.

Bostan, N., Örsal, Ö., \& Karadağ, E. (2016). Sağlığı geliştirici ve koruyucu davranışlar olceğinin geliştirilmesi: metodolojik calışma. Türkiye Klinikleri J Nurs Sci, 8(2), 102-111. https://doi.org/10.5336/nurses.2014-41578.

Cihangiroğlu, Z., \& Deveci, S.E. (2011). Firat üniversitesi Elazığ sağlık yüksekokulu öğrencilerinin sağlıklı yaşam biçimi davranışları \& etkileyen faktörler. Fırat Tip Dergisi, 16(2), 78-83.

Evren, H. (2008). Trakya üniversitesi öğrencilerinin riskli sağllk davranışları ve sağllk hizmeti kullanımları. Yüksek Lisans Tezi, Trakya Üniversitesi, Sağlık Bilimleri Enstitüsü, Edirne.

Güngör, İ., \& Hotun, Ş.N. (2006). Sağlığın geliştirilmesinde kullanılan temel davranış değiştirme, Kuram ve Modelleri. Hemşirelik Forumu, 2(2), 6-13.

İlhan, N., Batmaz, M., \& Akhan, L.U. (2010). Healthy lifestyle behaviors of university students. Maltepe Üniversitesi Hemşirelik Bilim ve Sanatı Dergisi, 3(3), 34-44. https://doi.org/10.1017/S1049023X17005544.

Karadeniz, G., Uçum, E.Y., Dedeli Ö., \& Karaağaç, Ö. (2008). Üniversite öğrencilerinin sağlıklı yaşam biçimi davranışları. TSK Koruyucu Hekimlik Bülteni, 7(6), 497-502.

Koçoğlu, D. (2006). Konya kent merkezinde saglıklı yasam biçimi davranıslart ve yasam kalitesinde sağllkta sosyo-ekonomik eşitsizlikler. Yüksek Lisans tezi, Selçuk Üniversitesi, Sağlık Bilimleri Enstitüsü, Konya.

Kong, R. (1995). Building community capacity for health promotion: a challange for public health nurses. Public Health Nursing, 12(5), 312-318. https://doi.org/10.1111/j.1525-1446.1995.tb00154.x.

Kostak, M.A., Kurt, S., Süt, N., Akarsu, Ö., \& Ergül, G.D. (2014). Healthy lifestyle behaviors of nursing and classroom teaching students. Taf Prev Med Bull, 13(3), 189-196. https://doi.org/10.5455/pmb.1-1362174271

Özkan, S., \& Yılmaz, E. (2008). Hastanede çalışan hemşirelerin sağlıklı yaşam biçimi davranışları. Fırat Sağllk Hizmetleri Dergisi, 3(7), 89-105.

Öztek, Z., Üner, S., \& Eren, N. (2012). Halk sağlığı kavramı ve gelişmesi. In Güler Ç, Akın L. (Ed.), Halk Sağll̆ğ Temel Bilgiler (2nd ed.). Ankara: Hacettepe Üniversitesi Yayınları.

Özvarış, Ş.B. (2011). Sağglı̆̆ Geliştirme ve Sağlık Ĕgitimi. Ankara: Hacettepe Üniversitesi Yayınları.

Sümen, A., \& Öncel, S. (2017). Factors that affect healthy lifestyle behaviors of high school students in Turkey: A systematic review. European Journal of Therapeutics, 23, 74-82. https://doi.org/10.5152/EurJTher.2017.04044

Tambağ, H. (2011). Hatay health school students' healthy lifestyle behaviors and influencing factors. Hacettepe University Faculty of Health Sciences Nursing Journal, 18(2), 47-58.

Tokuç, B., \& Berberoğlu, U. (2007). Edirne merkez ilçe ilköğretim okullarında çalışan öğretmenlerde sağlığı geliştirici davranışlar. Tsk Koruyucu Hekimlik Bülteni, 6(6), 421-426.

Turgul, Ö., Doğan, F., Mandıracığlu, A., \& Lüleci, E. (2002). Using of multidimensional health questionnaire with bausell' s measurement for evaluating the health promoting behaviour. Ege Tip Dergisi, 41(2), 91-95.

Vural, P.I., \& Bakır, N. (2015). Healthy life style behaviours and related influencing factors of the students of vocational school of health services. Acıbadem Üniversitesi Sağllk Bilimleri Dergisi, 6(1), 36-42. 
WHO. (2011). Health for all in the 21 st century. Retrieved from http://www.euro.who.int/data/assets/pdffile/000 3/88590/EHFA5-E.pdf Erişim tarihi: 24 Ekim 2011.

Yalçınkaya, M., Özer, F.G., \& Karamanoğlu, A.Y. (2007). Evaluation of healthy lifestyle behaviors in health care workers. Tsk Koruyucu Hekimlik Bülteni, 6(6), 409-420.

Yardım, N., Gögen, S., \& Mollahaliloğlu, S. (2009). Sağlı̆̆ın geliştirilmesi: Dünyada ve Türkiye'de mevcut durum. İstanbul Üniversitesi İstanbul Tip Fakültesi Dergisi, 72(1), 29-35.

Yılmazel, G., Çetinkaya, F., \& Naçar, M. (2013). Health promoting behaviors in nursing students. Tsk Koruyucu Hekimlik Bülteni, 12(3), 261-270.

Zaybak, A., \& Fadıllığlu Ç. (2004). Üniversite öğrencilerinin sağlığı geliştirme davranışı ve bu davranış1 etkileyen etmenlerin belirlenmesi. Ege Üniversitesi Hemşirelik Yüksek Okulu Dergisi, 20(1), 77-95. https://doi.org/10.5455/pmb.1-1334227851. 